\title{
Strategi Pemberdayaan Masyarakat Melalui Tabur Puja dan Bank Sampah di Posdaya Permata Bunda Kelurahan Gunung Sarik Kecamatan Kuranji
}

Intan Ratna Juita, Fatmariza

Program Studi Pendidikan Pancasila dan Kewarganegaraan

Universitas Negeri Padang

E-mail: intanratna.juita@yahoo.com

\section{ABSTRAK}

Saat ini masih terdapat masyarakat miskin yang yang dinilai belum mampu dalam mencukupi kebutuhan dasarnya sehari-hari. Hal ini terjadi pada masyarakat pra sejahtera khususnya pada masyarakat yang belum diberdayakan untuk mampu menciptakan mata pencahariannya sendiri atau untuk meningkatkan pendapatan dalam keluarga. Tujuan dari artikel ini yaitu untuk mendeskripsikan strategi pemberdayaan masyarakat melalui Tabur Puja dan Bank Sampah di Posdaya Permata Bunda dan dampak yang diperoleh anggota melalui pemberdayaan yang dilakukan Tabur Puja dan Bank Sampah. Informan penelitian ditentukan secara purposive yang berjumlah 12 orang yang terdiri dari Ketua Posdaya Permata Bunda, Pengurus Bank Sampah, Pengurus Koperasi, Anggota Tabur Puja, dan Nasabah Bank Sampah. Data dikumpulkan melalui wawancara, observasi, dan dokumentasi. Selanjutnya data dianalisis mengacu kepada tahapan analisis data Milles dan Huberman dengan tahapan yaitu reduksi data, penyajian data, pemeriksaan kesimpulan dan verifikasi. Hasil penelitian menunjukkan bahwa strategi pemberdayaan masyarakat yang dilakukan Tabur Puja yaitu melalui sosialisasi, pemberian motivasi, analisis usaha, pemberian pinjaman, survey ke tempat usaha, dan pertemuan rutin. Sedangkan pada Bank Sampah yaitu melalui sosialisasi, pemberian motivasi, menyetor sampah, pelatihan membuat kerajinan, dan pertemuan rutin. Dampak yang diperoleh anggota melalui Tabur Puja yaitu dampak ekonomi yang meningkatkan penghasilannya. Sedangkan pada Bank sampah, dampak yang diperoleh nasabah juga dampak ekonomi dan dampak lingkungan yang menjadikan lingkungan bersih, sehat, dan nyaman.

Kata Kunci: strategi, pemberdayaan masyarakat, Posdaya, Tabur Puja, Bank Sampah

\section{ABSTRACT}

Currently there are still poor people who are judged to be unable to meet their basic daily needs. This occurs in underprivileged communities, especially in communities that have not been empowered to be able to create their own livelihoods or to increase income in the family. The purpose of this article is to describe the strategy of community empowerment through Tabur Puja and Bank Sampah in Posdaya Permata Bunda, and the impact obtained by members through empowerment by Tabur Puja and Bank Sampah. The informants of the 
study were determined purposively with a total of 12 people consisting of the Head of Posdaya Permata Bunda, the Management of the Bank Sampah, the Management of the Cooperative, the Member of Tabur Puja, and the Customer of the Bank Sampah. Data was collected for 2 months through interviews, observation and documentation. Furthermore, the analyzed data refers to the Milles and Huberman data analysis stages with the stages of data reduction, data presentation, conclusion checking and verification. The results showed that the community empowerment strategy undertaken by Tabur Puja was through socialization, motivation, business analysis, lending, surveys to business sites, and routine meetings. Whereas at the Bank Sampah, namely through socialization, motivating, depositing waste, training to make crafts, and routine meetings. Impacts obtained by members through Puja Tabur are economic impacts that increase their income. Whereas at a Bank Sampah, the impact that the customer receives is also the economic and environmental impact that makes the environment clean, healthy and comfortable.

Keywords : strategy, empowerment community, Posdaya, Tabur Puja, Bank Sampah 


\section{PENDAHULUAN}

Pemberdayaan merupakan upaya untuk membangun kemampuan masyarakat dengan cara mendorong, memotivasi, dan membangkitkan kesadaran akan potensi yang dimilikinya. Pemberdayaan masyarakat juga merupakan strategi perubahan sosial secara terencana yang bertujuan untuk mengatasi masalah yang terjadi dalam masyarakat salah satunya yaitu kemiskinan. Oleh karena itu perlu adanya suatu program yang dapat memberdayakan masyarakat dalam mengatasi permasalahan khususnya kemiskinan untuk mencapai kesejahteraan hidup pada masyarakat yang ekonominya rendah. Salah satu program tersebut adalah Pos Pemberdayaan Keluarga (Posdaya).

Posdaya merupakan sebuah kegiatan pemberdayaan masyarakat yang mengimplementasikan nilai-nilai kegotong-royongan di masyarakat. Sasaran dari posdaya adalah masyarakat pra sejahtera yang dinilai belum mampu dalam mencukupi kebutuhan keluarga sehari-hari. Pelaksanaan pemberdayaan Posdaya Permata Bunda terbagi atas empat pilar yaitu pilar pendidikan, kesehatan, lingkungan, dan ekonomi yang berhubungan dengan kepentingan masyarakat yaitu untuk membantu mengatasi permasalahanpermasalahan yang ada dalam masyarakat khususnya pada masyarakat miskin. Upaya ini juga sekaligus membantu programprogram pemerintah dalam mengentaskan kemiskinan.

Penelitian yang dilakukan oleh Muljono, dkk (2016) menyatakan bahwa posdaya memiliki berbagai program atau kinerja untuk pemberdayaan masyarakat yaitu program pendidikan, kesehatan, kesekretarian, kemitraan, ekonomi, dan lingkungan. Hal yang sama juga diungkapkan Mardi (2018) menyatakan terbentuknya sejumlah pengurus posdaya menjadi penggerak kegiatan masyarakat melalui posdaya. Kegiatan yang dimaksud yaitu pembentukan dan pengembangan posdaya untuk kegiatan dalam beberapa bidang seperti pendidikan, kesehatan, dan wirausaha. Selanjutnya penelitian dari Kusumadinata dan Fitriah (2016) menyatakan kegiatan posdaya yang dilakukan adalah kegiatan berdasarkan pada kebutuhan yang sesuai di masyarakat yaitu kegiatan berupa lingkup ekonomi, pendidikan, kesehatan, dan lingkungan.

Sedangkan penelitian dari Yannefri (2016) menyatakan 
posdaya merupakan bentuk kelembagaan yang sesuai dengan semangat kegotongroyongan masyarakat yang mengoperasionalisasikan program pengentasan kemiskinan yang disusun dan dilaksanakan oleh masyarakat serta diperuntukkan untuk masyarakat. Serta penelitian dari Syamsuadi dan Zainuddin (2018) menyatakan perlunya meningkatkan partisipasi aktif dari masyarakat untuk melakukan kegiatan-kegiatan pemberdayaan yang mengarah pada tujuan posdaya yaitu ekonomi, pendidikan, kesehatan agar konsep pemberdayaan yang ideal dapat diwujudkan.

Adapun perbedaan antara penelitian ini dengan penelitian terdahulu yaitu didalam penelitian penulis hanya mendeskripsikan strategi pemberdayaan dan dampak pemberdayaan dari kedua program saja yaitu Tabur Puja dan Bank Sampah terhadap masyarakat. Sedangkan penelitian terdahulu mengemukakan kinerja posdaya dalam beberapa program seperti pendidikan, lingkungan, ekonomi, dan kesehatan. Akan tetapi tidak semua program tersebut dapat berjalan secara maksimal, dan mendapatkan partisipasi penuh dari masyarakat. Berbeda dengan penelitian yang penulis lakukan yaitu di Posdaya Permata Bunda, Tabur Puja dan
Bank Sampah dinilai sudah cukup baik dalam memberdayakan masyarakat. Selain itu partisipasi masyarakat dinilai cukup aktif dalam mengikuti kegiatan-kegiatan yang ada dalam program tersebut.

Menurut Badan Pusat Statistik pada tahun 2018 jumlah penduduk miskin di kota Padang berjumlah sekitar 44.04 ribu orang atau sekitar 4,7 persen dari total penduduknya yang berjumlah sekitar 944.919 orang. (Sumber: Kantor Badan Pusat Statistik (BPS) Sumatera Barat dan Padang). Salah satu kelurahan yang berada di kota Padang yaitu Kelurahan Gunung Sarik Kecamatan Kuranji memiliki jumlah penduduk mencapai 17.879 jiwa dengan jumlah kartu keluarga (KK) sebanyak 4.307 KK. Sebanyak 191 KK diantaranya adalah KK masyarakat yang miskin. (Sumber: Badan Pusat Statistik Kota Padang Tahun 2018). Hal ini dapat dilihat bahwa masih terdapat masyarakat miskin yang dinilai belum mampu dalam memenuhi kebutuhan hidupnya sehari-hari. Oleh karena itu permasalahan yang peneliti dapatkan dalam artikel ini yaitu masih terdapat masyarakat miskin yang belum diberdayakan di Kelurahan Gunung Sarik Kecamatan Kuranji.

Tujuan dari artikel ini adalah untuk mendekripsikan bagaimana strategi pemberdayaan masyarakat yang dilakukan oleh Tabur Puja 
dan Bank Sampah, serta dampak yang diperoleh anggota melalui pemberdayaan yang dilakukan sehingga hasil deskripsi ini bermanfaat untuk masyarakat khususnya pada masyarakat pra sejahtera. Manfaat lain yaitu sebagai masukan terhadap Posdaya Permata Bunda agar lebih memaksimalkan kinerja programprogram dalam memberdayakan masyarakat, dan sebagai masukan untuk pemerintah agar lebih mendukung secara nyata kegiatankegiatan yang dilakukan oleh Posdaya Permata Bunda.

\section{METODE PENELITIAN}

Jenis penelitian yang digunakan adalah penelitian kualitatif dengan analisis data secara deskriptif yang bertujuan untuk menggambarkan atau mendeskripsikan kondisi dan situasi yang sebenarnya yaitu bagaimana strategi pemberdayaan masyarakat yang dilakukan oleh Tabur Puja dan Bank Sampah dan dampak yang diperoleh anggota dari pemberdayaan tersebut di Posdaya Permata Bunda Kelurahan Gunung Sarik Kecamatan Kuranji. Informan penelitian ditentukan secara purposive yang berjumlah 12 orang yang terdiri dari Ketua Posdaya Permata Bunda, Pengurus Bank Sampah, Pengurus Koperasi, Anggota Tabur Puja, dan Nasabah Bank Sampah. Jenis data yang digunakan dalam penelitian ini adalah data primer dan data sekunder. Data dikumpulkan selama 2 bulan melalui wawancara, observasi, dan dokumentasi. Uji keabsahan data dengan menggunakan teknik triangulasi data. Selanjutnya data dianalisis mengacu kepada tahapan analisis data Milles dan Huberman dengan tahapan yaitu reduksi data, penyajian data, pemeriksaan kesimpulan dan verifikasi.

\section{HASIL DAN PEMBAHASAN}

\section{Strategi pemberdayaan masyarakat yang dilakukan oleh Tabur Puja}

Tabur Puja merupakan program dari Yayasan Damandiri yaitu simpan pinjam untuk anggota yang ingin membuka usaha dan juga untuk menambah modal usaha. Besarnya pinjaman yang diberikan yaitu antara Rp. 500.000 hingga Rp. 5.000.000 ditambah simpanan wajib sebesar Rp. 1250,00 yang dibayar perminggu, simpanan pokok dan simpanan sukarela. Tenggang waktu pengembalian dana pinjaman yang diberikan antara 6-12 bulan. Jumlah anggota yang pernah mengikuti Tabur Puja yaitu sebanyak 110 orang, anggota yang masih aktif sampai saat ini berjumlah 26 orang. Strategi pemberdayaan melalui program Tabur Puja, yaitu: 
1. Melakukan sosialisasi dan pemberian motivasi

Pada Tabur puja, strategi pertama yang dilakukan oleh pengurus Posdaya dan Koperasi adalah melakukan kegiatan sosialisasi untuk memperkenalkan Tabur Puja kepada masyarakat. Sosialisasi dilakukan di berbagai pertemuan-pertemuan, misalnya pertemuan PKK, pertemuan Posyandu, dan lain-lain. Posdaya menyampaikan informasi mengenai Tabur Puja, bagaimana sistem kerjanya, manfaat mengikuti, dan sebagainya. Masyarakat juga diberikan motivasi dan diajak agar mau mengikuti Tabur Puja khususnya pada masyarakat yang memiliki ekonomi yang rendah.

Hal ini diperkuat oleh temuan penelitian terdahulu yaitu oleh Noviani (2015) yang menyatakan bahwa sosialisasi diperlukan untuk mengembangkan posdaya dengan mengenalkan beberapa kegiatan atau program untuk meningkatkan partisipasi masyarakat dalam mengikuti kegiatan atau program. Teori yang berkaitan dengan artikel ini yaitu teori Suharto (dalam Mardikanto dan Poerwoko, 2015: 170-171) terhadap strategi pemberdayaan masyarakat, ia mengemukakan ada lima aspek penting yang dapat dilakukan dalam melakukan pemberdayaan masyarakat salah satunya yaitu melalui motivasi dimana masyarakat diberikan motivasi melalui sosialisasi terlibat dalam kegiatan yang dapat meningkatkan pendapatan.

2. Melakukan analisis usaha dan penyeleksian

Setelah melakukan sosialisasi untuk memperkenalkan Tabur Puja kepada masyarakat, maka bagi masyarakat yang merasa tertarik dan ingin mengikuti Tabur Puja datang ke Posdaya Permata Bunda untuk mendaftar menjadi anggota. Syarat untuk mendaftar yaitu membawa kartu keluarga KK dan KTP. Lalu setelah anggota mendaftar, maka anggota akan diwawancarai terlebih dahulu oleh pengurus Koperasi. Pengurus dari Koperasi yang datang langsung ke Posdaya dan melakukan wawancara kepada anggota. Setelah itu, pihak dari pengurus Koperasi dan pengurus Posdaya akan melakukan seleksi untuk siapa-siapa saja anggota yang diterima. Pihak Posdaya akan merekomendasikan apakah orang tersebut layak atau tidak untuk dibantu.

3. Memberikan pinjaman

Setelah dilakukan analisis usaha dan penyeleksian, maka anggota yang diterima dapat mengajukan pinjaman untuk membuka usaha atau menambah 
modal usaha. Besarnya pinjaman yang diberikan antara Rp.500.000 hingga Rp. 5.000.000. Akan tetapi untuk anggota baru biasanya akan diberi pinjaman maksimal Rp. 2.000.000. Jangka waktu pengembalian yang diberikan yaitu antara 6-12 bulan. Jika usaha yang dilakukan oleh anggota dinilai sudah cukup berhasil, maka dia bisa meminjam dalam jumlah yang lebih besar yaitu diatas Rp. 3.000.000.

Hal ini sama dengan yang dijelaskan penelitian terdahulu yaitu oleh Noviani (2015) yang menyatakan Tabur Puja diperuntukkan untuk masyarakat yang ingin membuka usaha dan juga menambah modal usaha. Selain itu kelenturan dalam sistem "Tabur Puja" adalah anggota dapat menentukan tenggang waktu pengembalian dana pinjaman antara 6-12 bulan.

4. Melakukan survey ke tempat usaha

Pihak koperasi melakukan survey atau pengamatan langsung ke tempat usaha yang dijalankan para anggota. Tujuannya yaitu untuk melihat apakah anggota tersebut memang benar melakukan usahanya atau tidak. Pengamatan usaha tersebut dilakukan sebelum ada peminjaman baru. Hal tersebut juga dikatakan oleh penelitian terdahulu yaitu oleh Noviani (2015) yang menyatakan perlunya bagi pengurus untuk melakukan pengamatan langsung ke lapangan tempat anggota melakukan usahanya

\section{Melakukan pertemuan rutin}

Pada program ini dilakukan pertemuan rutin oleh pengurus Posdaya, pengurus Koperasi, dan anggota. Pertemuan rutin dilakukan setiap tiga bulan sekali di kantor Koperasi atau di Posdaya Permata Bunda. Pada pertemuan rutin ini, pengurus dan anggota membahas segala hal yang menyangkut Tabur Puja, misalnya masalah peminjaman, pengembalian angsuran oleh masyarakat yang sering terlambat, serta membahas solusi dari masalah-masalah tersebut.

Hal ini juga sesuai dengan penelitian terdahulu yaitu oleh Noviani (2015) yang menyatakan pengurus dan anggota perlu melakukan pertemuan rutin mingguan. Teori yang berkaitan dengan artikel ini yaitu teori Suharto (dalam Mardikanto dan Poerwoko, 2015: 170-171) terhadap strategi pemberdayaan masyarakat, aspek yang dilakukan yaitu melalui manajemen diri yaitu perencanaan, pengorganisasian, dan pengontrolan sumber daya untuk mencapai suatu keadaan yang ideal. Kegiatan tersebut dilakukan dengan melaksanakan pertemuan- 
pertemuan, melakukan pencatatan dan pelaporan, mengoperasikan tabungan dan kredit, resolusi konflik serta manajemen kepemilikan masyarakat.

\section{Strategi pemberdayaan masyarakat yang dilakukan oleh Bank Sampah}

Bank Sampah merupakan program Posdaya di bagian pilar lingkungan. Bank Sampah merupakan program yang memanfaatkan sampah-sampah jenis anorganik untuk dijual kembali atau diolah kembali menjadi suatu kerajinan. Bank Sampah ini memiliki mitra kerjasama dengan PT Pegadaian. Jumlah nasabah yang mengikuti Bank Sampah yaitu sebanyak 184 orang. Strategi-strategi pemberdayaan melalui program Bank Sampah, yaitu:

1. Melakukan sosialisasi dan pemberian motivasi

Pada Bank sampah, strategi pertama yang dilakukan oleh pengurus juga melakukan sosialisasi dan pemberian motivasi terhadap masyarakat dan tokoh masyarakat. Sosialisasi dilakukan di berbagai pertemuan-pertemuan misalnya pertemuan PKK dan ketika ada event atau acara di lurah maka pihak Bank Sampah akan menyampaikan program Bank Sampah seperti bagaimana sistem kerjanya, jadwalnya kapan saja, jenis sampah yang diterima, serta manfaat yang didapatkan jika mengikuti Bank Sampah.

Menurut penelitian terdahulu oleh Maulidah (2017) menyatakan bahwa pengurus perlu melakukan sosialisasi dan kampanye mengenai pentingnya bank sampah kepada masyarakat oleh tokoh masyarakat atau pihak yang terkait untuk meningkatkan partisipasi masyarakat menjadi nasabah di bank sampah.

Teori yang berkaitan yaitu teori Suharto (dalam Mardikanto dan Poerwoko, 2015: 170-171) terhadap strategi pemberdayaan masyarakat, yang mengemukakan ada beberapa aspek dalam melakukan pemberdayaan masyarakat salah satunya yaitu melalui motivasi, yang dimana masyarakat diberikan motivasi melalui kegiatan sosialisasi agar terlibat dalam kegiatan tersebut.

\section{Menyetor Sampah}

Salah satu kegiatan yang ada dalam Bank Sampah adalah menyetorkan sampah yang sudah dikumpulkan nasabah dari lingkungan tempat tinggalnya maupun di tempat lain. Sampah yang sudah disetor akan dijual kembali oleh Bank sampah. Hasil dari penjualan sampah tersebut akan dimasukkan ke dalam buku tabungan yang dikumpulkan secara bertahap-tahap. Apabila 
tabungannya sudah berjumlah banyak maka akan dapat ditukarkan dengan uang atau emas sesuai dengan jumlah tabungan nasabah.

Hal serupa juga dikatakan penelitian terdahulu oleh Maulidah (2017) menyatakan bahwa nasabah bank sampah wajib menyetorkan sampahnya agar dapat ditukarkan dengan uang atau emas. Teori yang berkaitan dengan ini yaitu teori Suharto (dalam Mardikanto dan Poerwoko, 2015: 170-171) terhadap strategi pemberdayaan masyarakat, yang menyatakan aspek mobilisasi sumberdaya merupakan upaya yang memastikan tercukupinya sumber daya. Setiap masyarakat memiliki sumber nya sendiri yang jika dihimpun, dapat meningkatkan kehidupan sosial ekonomi secara substansial. Hal ini juga sama persis dengan Bank Sampah, yang dimana nasabah memiliki sumber dayanya sendiri yaitu sampah-sampah yang mereka kumpulkan dari lingkungan tempat tinggal mereka.

3. Melakukan pelatihan untuk membuat kerajinan

Kegiatan lain di Bank sampah yaitu melakukan pelatihan antara pengurus dan nasabah untuk membuat suatu kerajinan. Bahan yang digunakan yaitu dari sampah yang disetor seperti plastik, koran, karton, dan lain-lain.
Bagi nasabah yang ingin membuat suatu kerajinan atau produk bisa mengikuti pelatihan yang dilakukan oleh pengurus Bank Sampah, setelah nasabah sudah mengetahui cara membuatnya maka dia dapat membuat sendiri kerajinannya, setelah itu kerajinan atau produk tersebut akan dijualkan. Hal ini tentunya dapat menciptakan mata pencaharian atau usaha sampingan nasabah itu sendiri.

Sesuai dengan penelitian terdahulu yang dilakukan oleh (Hanafiah Maulidah, 2017) menyatakan bahwa keikutsertaan dalam pelatihan pengelolaan sampah adalah kesediaan nasabah untuk mulai belajar mengelola sampah menjadi barang yang memiliki nilai ekonomi. Teori yang sesuai yaitu teori Suharto (dalam Mardikanto dan Poerwoko, 2015: 170-171) terhadap strategi pemberdayaan masyarakat yang menyatakan aspek peningkatan kesadaran dan pelatihan kemampuan bertujuan untuk membantu masyarakat khususnya pada masyarakat miskin agar dapat menciptakan mata pencaharian mereka sendiri atau membantu masyarakat untuk meningkatkan keahlian dalam menciptakan suatu produk. 
4. Melakukan pertemuan rutin Pada program ini juga dilakukan pertemuan rutin oleh pengurus Bank sampah dan nasabah. Pertemuan rutin dilakukan setiap lima minggu ke empat di gedung Bank Sampah Panca Daya. Pada pertemuan rutin ini, pengurus dan nasabah membahas segala hal yang menyangkut program Bank Sampah seperti masalah yang ada dalam pelatihan, masalah penjualan produk, serta solusi dari permasalahan tersebut. Teori yang berkaitan dengan ini yaitu teori Suharto (dalam Mardikanto dan Poerwoko, 2015: 170-171) terhadap strategi pemberdayaan masyarakat, yang menyatakan aspek manajemen diri yaitu perencanaan, pengorganisasian, dan pengontrolan sumber daya untuk mencapai suatu keadaan yang ideal. Kegiatan tersebut dilakukan dengan melaksanakan pertemuanpertemuan, melakukan pencatatan dan pelaporan, mengoperasikan tabungan dan kredit, resolusi konflik serta manajemen kepemilikan masyarakat.

Dampak yang diperoleh anggota dari pemberdayaan melalui Tabur Puja dan Bank Sampah

\section{a. Program Tabur Puja}

Program Tabur Puja memiliki dampak yang positif bagi anggota masyarakat yang mengikuti.
Masyarakat yang pada awalnya belum cukup terpenuhi kebutuhan dasarnya yaitu kebutuhan dalam sandang, pangan, papan, pendidikan, kesehatan, dan lainlain, sekarang sudah terpenuhi berkat bantuan pinjaman dari program Tabur Puja. Dampak program Tabur Puja dari segi ekonomi sangat membantu masyarakat, berkat usaha yang dilakukan oleh masyarakat melalui pinjaman tersebut mampu meningkatkan penghasilannya, sehingga kebutuhan dasar dalam keluarga dapat terpenuhi sehingga tercapailah kesejahteraan keluarga.

Hal ini diperkuat oleh temuan penelitian terdahulu yaitu oleh Noviani (2015) yang menyatakan bahwa Tabur puja memiliki kegiatan ekonomi seperti usahausaha kecil dibidang pangan, kerajinan, maupun jasa. Hal ini membuat anggota dengan keterbatasan merasa terbantu dalam kehidupannya untuk meningkatan kesejahteraan keluarga.

b. Program Bank Sampah

Program Bank Sampah juga memiliki dampak positif bagi masyarakat yang mengikuti. Pada dampak ekonomi, masyarakat dapat meningkatkan pendapatan mereka melalui hasil penjualan sampah yang sudah disetor dan melalui kerajinan atau produk yang 
sudah dijualkan. Sedangkan pada dampak lingkungan yaitu semenjak masyarakat aktif dalam mengumpulkan sampah-sampah yang ada disekitar lingkungannya, lingkungan tempat tinggal pun menjadi bersih, sehat, nyaman, dan terhindar dari penyakit.

Menurut penelitian terdahulu yang dilakukan oleh Anggraini (2013) menyatakan Bank sampah mendaur ulang sampah yang memiliki pengertian sebagai proses menjadikan bahan bekas menjadi bahan baru yang dapat digunakan kembali, lalu dijual dan hasil penjualannya tersebut bermanfaat dalam menambah ekonomi warga. Selain itu, dampak yang diperoleh juga warga dapat menciptakan lingkungan yang bersih dan bebas dari sampah.

$\begin{array}{crr}\text { Hasil } & \text { penelitian } & \text { ini } \\ \text { menunjukkan } & \text { bahwa } & \text { ada }\end{array}$ kesesuaian dengan teori yang dinyatakan oleh Mardikanto dan Poerwoko (2015: 28) yaitu pemberdayaan mengandung arti perbaikan mutu hidup atau kesejahteraan setiap individu dan masyarakat, salah satunya yaitu perbaikan ekonomi, terutama kecukupan pangan, dan perbaikan kesejahteraan sosial seperti pendidikan dan kesehatan.

\section{KESIMPULAN}

Berdasarkan hasil penelitian dan pembahasan yang yang telah dilakukan dapat disimpulkan bahwa Tabur Puja dan Bank Sampah dinilai sudah cukup membantu masyarakat dalam mengatasi masalah yang terjadi yaitu kemiskinan. Hal ini dapat dilihat dari peran Tabur Puja dan Bank Sampah yang memiliki beberapa strategi untuk memberdayakan masyarakat. Tujuan dari kedua program yaitu untuk meningkatkan penghasilan masyarakat khususnya pada masyarakat miskin agar dapat memenuhi kebutuhannya seharihari. Dampak yang didapatkan oleh masyarakat melalui Tabur puja dan Bank sampah dinilai memiliki dampak yang positif seperti dampak ekonomi untuk meningkatkan penghasilan masyarakat dan dampak lingkungan untuk menciptakan lingkungan tempat tinggal yang bersih, sehat, dan nyaman.

\section{DAFTAR PUSTAKA}

Mardikanto, Totok \& Soebiato, Poerwoko. 2015. Pemberdayaan Masyarakat Dalam Perspektif Kebijakan Publik. Bandung: Penerbit Alfabeta.

Muljono, Pudji., dkk. 2011. 101 Cara Mengenal Posdaya. Bogor: IPB Press.

Sugiyono. 2013. Metode Penelitian Pendidikan (Pendekatan Kuantitaif, Kualitatif, dan 
R\&D). Bandung: Penerbit Alfabeta.

Moleong. 2009. Metode Penelitian Kualitatif. Bandung: PT Remaja Rosdakarya.

Muljono, Pudji., dkk. 2016. Evaluasi Kinerja Posdaya Sebagai Program Pemberdayaan Masyarakat. Jurnal Sosiohumaniora. No $2 \mathrm{Vol}$ 18. Hlm. 123-130.

Karlina, Restu., dkk. 2016. Analisis Implementasi Kebijakan Pos Pemberdayaan Keluarga (Posdaya) di Kota Malang. Jurnal Ilmu Pemerintahan. No 6 Vol 2. Hlm. 112-119.

Mardi. 2018. Pemberdayaan Masyarakat Melalui Kegiatan Posdaya Pada Kecamatan Jatinegara Jakarta Timur. Jurnal Pemberdayaan Masyarakat Madani. No 2 Vol 2. Hlm 355-371.

Syamsuadi dan Zainuddin. 2018. Strategi Pos Pemberdayaan Keluarga dalam Penguatan Fungsi Kelembagaan Sosial di Kelurahan Binawidya Kota Pekanbaru. Jurnal Dinamika Pemerintahan. No 2 Vol 2. Hlm 99-109.

Kusumadinata dan Fitriah. 2016. Analisis Komunikasi Partisipasi Pos Pemberdayaan Keluarga (Posdaya) di Kota Bogor.
Jurnal Komunikatio. No 2 Vol 2. Hlm 97-106.

Bachtiar, Yannefri. 2016. Posdaya Bina Sejahtera Kota Bogor sebagai Model pemberdayaan Kemandirian Masyarakat Akar Rumput. Jurnal Ilmiah Pengabdian kepada Masyarakat. No 1 Vol 2. Hlm 31-38.

Noviani, Annisa. 2015. Hubungan Antara Tingkat Partisipasi Anggota Dengan Kelancaran Program Tabur Puja di Posdaya Sejahtera Kota Bogor. Skripsi: IPB

Maulidah, Hanafiah. 2017. Analisis Potensi Nilai Ekonomi Sampah Dalam Pengelolaan Sampah Berbasis Masyarakat (Studi Kasus: Bank Sampah Srikandi Berdikari, Desa Pasarean, Kabupaten Bogor). Skripsi: IPB

Anggarini, Jean. 2013. Dampak Bank Sampah Terhadap Kesejahteraan Masyarakat dan Lingkungan (Studi Kasus Bank Sampah Cempaka II di Kelurahan Pondok Petir Rw: 09) Bojongsari Kota Depok. Skripsi: UIN 